\title{
Critical stress factors influencing architecture students in Turkey: a structural equation modelling approach
}

\author{
Gülden Gümüşburun Ayalp
}

Department of Architecture, Hasan Kalyoncu Uiversity, Gaziantep, Turkey, and

\author{
Tülay Çivici \\ Department of Architecture, Balikesir University, Balikesir, Turkey
}

\begin{abstract}
Purpose - Presently, there are two main classification of architectural courses in the curriculum: lecture courses and design studios. Owing to the duality between design studios and lecture courses, architectural education includes a highly stressful learning environment. In addition to this dualism, architecture students also cope with their lives in universities and different types of stressors similar to all university students. Therefore, this study aims to determine the critical stress factors that affect architecture students studying in Turkey.
\end{abstract}

Design/methodology/approach - The reasons for a stressful architecture learning environment were examined using a questionnaire distributed among architecture students, and face-to-face surveys were conducted. The obtained data were analysed statistically using SPSS 22 and LISREL 8.7 software. Correlation analysis, exploratory and confirmatory analysis and structural equation modelling of the relationships between the stressors and stress factors and the impacts (perceived stress) were performed, and a structural model was developed.

Findings - A total of 11 critical factors affecting architecture students' stress levels were determined; academic inadequacy, unusual assessments and evaluation techniques of courses and intensive academic schedule were the most critical stressors. Based on these factors, necessary solutions and recommendations were offered, which are expected to decrease architecture students' stress levels and encourage other similar studies.

Originality/value - There is limited research that provides insights into the factors that cause stress to architecture students; only literature reviews and surveys are currently available. Unlike these, this study presents a structural equation model for critical stress factors via a confirmatory factor analysis.

Keywords Architectural education, Stress, Structural equation modeling, Socially and culturally sustainable architecture and urban design

Paper type Research paper

\section{Introduction}

The term "stress", meaning hardship or adversity, is found to be used without a programmatic focus, at least as early as the from 14th century (Lumsden, 1981). Since that period, the use of the term "stress" has somewhat changed from transitional physics to other disciplines. Hooke's analysis significantly affected early-century models of stress in physiology, psychology and sociology domains. Lazarus and Cohen (1977) considered three general classes of stressors. The first, cataclysmic phenomena, refers to sudden, unique and powerful single events affecting large numbers of people. The second class of stressors refers to powerful events that challenge the adaptive abilities in a manner similar to 
$\mathrm{OHI}$

46,2

cataclysmic events; however, they influence fewer people. Therefore, affiliative and socially comparative behaviours have been determined as strategies for coping with a focussed specific threat, and social support has been shown to mitigate the effect of stress; this distinction is significant. "Daily hassles" are referred to as the third group of stressors, which refer to the stable and repetitive problems encountered in daily life, including job satisfaction, neighbourhood problems and education problems (Baum et al., 1981).

Architectural education is known to be taught in an extremely demanding and stressful learning environment. The curricula demand that the architecture students adopt several proficiencies, including obtaining theoretical knowledge, technological competencies, design creativity and interpersonal skills. This unique education deviates significantly from anything that they acquire in their undergraduate education. Additionally, students are exposed to stressors analogous to those of architect practitioners during design studio and training.

Architecture students exhibiting significant stress symptoms during their education has been reported (Anthony, 1991; Kirkpatrick, 2018; Xie et al., 2019), and they have been more anxious than other students studying in other departments (RIBA Survey, 2017, 2018; Kirkpatrick, 2018).

Studies regarding architectural school life, mental problems and panic and occupational pressures suggest that both architectural practise and education include stress agitator factors that, generally, have negative effects on an individual's well-being. First, a case study was conducted and published in Architects' Journal in 2016 where students were questioned about their emotional burden for completing the seven-year course of architecture. Results showed that one in four architecture students in the UK had received treatment for mental health issues, and a further $26 \%$ feared that they would have to seek medical help in the future (Waite and Braidwood, 2016). Another survey conducted in 2018 indicated that this problem is deteriorating. The number of students is one in three at present (Jessel, 2018).

Experienced stress levels are largely linked to their causes because stress occurs when a person's adaptive response to a stimulus develops excessive physical or psychological burden for that person (Moorhead and Griffin, 1995). In an educational environment, these stressors are likely to be of a long-term nature, inducing physical and spiritual tiredness that affect and one's health, and affect one's perception of their ability to complete an assignment/project and finally deteriorate their learnability's. Additionally, educational environments may change with the impact of new educational technologies that affect the students' stress level and learning abilities.

The main aim of this study is to identify the major causes of stress experienced by architecture students in Turkey studying in two different types of universities (state and private). From the extended literature, it is possible to classify the sources of architecture students' stress into four main categories: individual, academic, interpersonal relation and environmental (Elias et al., 2011; Lin, 2012; Sawruk, 2015; Harvey et al., 2006). Within the scope of the four main contexts, items were defined from the literature and interviews with architecture students were conducted. Exploratory and confirmatory factor analyses were then conducted to determine the main types of the stressors included. A correlation analysis was used to determine the relationships among the stress factors and stress. Finally, a structural equation modelling (SEM) was applied to cross-check the inter-relationships among the stressors and establish an integrated stressor-stress model.

\section{Architectural education and stress}

Architecture is a discipline that draws knowledge from technology, humanities, environmental sciences, social and physical sciences, creative arts and liberal arts. Therefore, in other words, 
architecture is a multi-skilled, multidisciplinary, multidimensional and multimedia practise. For these reasons, architects must have knowledge about many crafts, technologies and theories and should have the ability to associate with stakeholders in various fields. Therefore,

architectural education should involve the acquisition of design, knowledge (about cultural and artistic, social, environmental, technical, design and professional study topics), and skill capabilities (UIA, 2011).

Architectural education is not an elementally professional education, which can be achieved by training only. The architectural education process is about teaching how to find and solve actual problems. In this respect, architectural education has its own specific properties, which makes it different from the practise of architecture and the education imparted in other disciplines. There are two main classifications of architectural courses in the curriculum: theoretical courses that associate history, technology and legal issues with design studios that enable creative exploration and the organisation of complex problems. The duality between the design studios and lectures results in a significant amount of workload. The annual “Architects' Journal Student Survey of 2019” concluded that architecture students confronted problems related with student loans, workloads, practical training and worries of the stress-induced illness (Waite and Jessel, 2019). Therefore, architectural education generates a highly stressful learning environment.

Parilla (2012) expressed stress as an instability between requirements and resources or when the mental pressure increases beyond one's perceived ability to cope. It is experienced by an individual if some factors, called stressors, trigger at sense of hopelessness: the individual lacks an overcoming mechanism, which leads to pressure. Based on this definition, stress is stimulated by stressors that cause imbalances in students' lives; therefore, dealing with stress is vital for creating a better study environment.

Stress is often mentioned as "negative emotions" which cause an increase in academic success of university students (Ahmed and Julius, 2015; Elias et al., 2011; Majumdar and Ray, 2010). These negative emotions are caused by the existence of sources of stress, or "stressors", in students' lives (Ahmed and Julius, 2015). These stressors are not just limited to domain of school work; they come from relationships, work, financial obligations, domestic life and other sources (Elias et al., 2011; Majumdar and Ray, 2010).

Being a first-year student can be discouraging (Ahmed and Julius, 2015; Elias et al., 2011) as the life-changing experience of moving to college caused students to experience reported increasing levels of negative emotions as they progress through their college experiences, with them being the highest in their final year (Elias et al., 2011; Majumdar and Ray, 2010). Baqutayan (2011) stated that architecture students adjusting to studio life is a significant challenge for incoming first-years. Baqutayan (2011), suggested that the students' high drop-out rate arises because students do not always know what they are getting themselves into.

Interpersonal relationships, workloads, university standards, poor learning conditions, uncertainty about the future, time management and scheduling and self-expectations are prime stressors experienced by undergraduate students (Ahmed and Julius, 2015; Elias et al., 2011; Majumdar and Ray, 2010). Negative emotions such as depression, stress and anxiety are stimulated by these stressors in students, causing negative impacts on their academic work.

Fridlander et al. (2007) reported that graduate and undergraduate students also experience a fear of failure regarding their grades and academic work.

Zawawi and Jye (2012) examined the factors related to the causes of stress and the overcoming strategies in the case of postgraduate students. The main stresses were identified 
$\mathrm{OHI}$

46,2

as academics-associated stress, time-associated stress and social/environmental-associated stress, with academic-related stress determined to be the major stressor among students.

When the subject was analysed from the viewpoint of architecture students, they expressed a low level of satisfaction with their educational experiences. Cuff (1991) argues that graduates become frustrated when they first enter architectural practise because of the uncertainty associated with this step. Nicol and Pilling (2000) are less specific in defining the problem, but they make it clear that it results from the gap between the student experience in school and the graduate experience in commercial practise. The former is highly unable to replicate a practising environment, whereas the latter is unable to simulate an educational environment. An additional explanation for graduates' dissatisfaction with their educational experiences relates to their workload. Architecture students complain of exhaustion, isolation and stress. Bachman and Bachman's (2006) analysis of students' workload identified that the extreme deprivation of sleep, poor diet, reduction of exercise and social inactivity are all common characteristics of the lives of architecture students. However, Bachman and Bachman (2006) also found that only one activity, design, accounted for the majority of the workload pressures. In particular, this design process also caused a range of anxieties that caused directly the feelings of dissatisfaction and depression among the students (Bachman and Bachman, 2006).

According to Ostwald and Williams (2008), students' concern and dissatisfaction arise from the processes of the discipline for assessing design. Students often have little confidence in their designs; have a low level of understanding of the discussion and advice they get in critiques; and are unable to articulate how they can develop their work. The ambiguity arising from this situation is responsible for causing too much stress and pressure related to the design studio and contributes to the emphasis students place on designs above all other curricular areas.

Architecture students affect each other in formal and informal capacities by interacting with many diverse groups of people within and outside their university and department. Therefore, interpersonal relationship stressors may include conflict with parents or family members, retaining a relationship with each other, making new friends and misunderstandings (Elias et al.2011; Lin, 2012; Sawruk, 2015). Moreover, they interact with many instructors and friends coming from different cultural backgrounds. In addition, some students work in the construction industry or other related areas, and while working, they sympathise with their employers and clients. Moreover, all architecture students undergo training at various architectural offices and construction sites during the summer. Within this period, they interact with many types of people, including construction workers and other stakeholders. These types of situations can knowingly or unknowingly bring about stress and tension, often pressurised on an individual, as a result of different values, distrust or an unjust micro-environment for these students. The negative emotions caused by these stressors are particularly dangerous because they reside outside of the confines of academia, and social support can frequently decrease the stress or is leveraged as a coping strategy (Majumdar and Ray, 2010; Szabo and Marian, 2017). Interpersonal relations are not strictly restricted to the non-academic areas of life. Misunderstandings with a professor regarding an assignment, conflicting personalities within a laboratory or project group or the incomprehension or availability of a supervisor/lecturer are often expressed as the difficulties students face in their academic settings (Lin, 2012).

The most remarkable source of stress for many architecture students is juries and examinations which may cause a variety of symptoms such as changes in eating habits and sleeping patterns, nausea and stomach pain in some students because of the stress related to exams (Gadzella and Baloglu, 2001). 
Although there are numerous researches on construction professionals' stress level ( $\mathrm{Ng}$ et al., 2005; Leung et al., 2011; Bowen et al., 2013; Chan et al., 2014; Nwaogu et al., 2020; Sun et al., 2020) and factors, the number of researches on architecture students' stress level and factors that induce stress is limited. Studies have already been conducted previously to determine the stressors in college students studying in disciplines other than architecture; however, studies on the stressors and their effects on architecture students do not exist. To date, studies on architecture students' stress have revealed limited number of causes of stress using only the literature review. Unlike other limited studies on this subject, a wide spectrum questionnaire was formed by surveying the literature and interviewing the architecture students. In addition, a structural equation model was developed to present the effect size and relationships between the stressors and stress. The most significant stressors could be determined as such. Therefore, this study is carried out to determine the stress level, sources of stress and stress factors of architectural students from first year to graduate level in Turkish universities.

\section{Methodology}

In the current study, a quantitative research design was used in which critical stress factors that could influence architecture students were identified and assessed. This research followed a multistage methodological framework: determination of items that will comprise the factors, design of the questionnaire as a measurement instrument, data collection and, finally, statistical analysis of the collected data.

\subsection{Determining stressors that cause stress among architecture students}

The method of determining stressors was performed in two phases. In the first phase, a review of the extensive literature was done to identify several stressors. In the second phase, researchers interviewed 32 university students. The distribution of the interviewed students according to university type was equal, and the participation in interviews was voluntary. Students from each year of architectural education were invited to the researchers' office at the university, and an open-ended question "what is the most important five stressors that cause stress for you during your education?" was asked to the students. Their responses were categorised according to the type of response. Finally, the major criteria (50 items) influencing the architecture students' stress are identified in Table 1.

\subsection{Design of the measurement instrument}

The prepared questionnaire comprised three parts for measuring the required variables. The first part was designed by researchers based on the literature review and interview results. Section 1 of the questionnaire was intended to obtain data about respondents' stressors caused by individual, interpersonal, academic and environmental variables. A total of 50 questions were included in this section, and they were measured on a five-point Likert scale.

The second part focussed on obtaining information about the respondents' personal and social-demographical properties. This section comprised five questions regarding the gender, type of university, age, year of education and grade point average.

The Perceived Stress Scale with 14 items (PSS-14) was used as an instrument to determine the architecture students' level of stress in the last section of the questionnaire. The items of PSS-14 were easily understandable, and the response alternatives were simple to grasp. The PSS-14 was previously generated by Cohen et al. (1989). PSS-14 includes 14 close-ended questions. The PSS-14 scores are acquired by summing all 14 items with seven scores reversed; for example, $0=4,1=3,2=2$, etc. The positive stated items are 4, 5, 6, 7, 9, 10 and 13. The PSS-14 has a possible range of scores from 0 to 56 , which were also divided 


\section{$\mathrm{OHI}$}

46,2

\begin{tabular}{|c|c|c|}
\hline No. & Stress indicators & Reference \\
\hline 1 & Fear of not finding a job & {$[2],[16],[19]$} \\
\hline 2 & Fear of not getting a high income & {$[12],[13]$} \\
\hline 3 & Uncertainties about future occupational life & {$[2],[3],[16],[18],[19]$} \\
\hline 4 & Permanent medical problems & {$[2],[3],[18]$} \\
\hline 5 & Home sickness & {$[3],[8],[9],[10]$} \\
\hline 6 & Engagement/marriage before graduation & {$[5],[8],[19]$} \\
\hline 7 & Lack of time to pursue hobbies & [2], [3], [8], [10], [11], [15], [17] \\
\hline 8 & $\begin{array}{l}\text { Changing university/department because of lateral } \\
\text { or vertical transfer }\end{array}$ & {$[2],[5],[19]$} \\
\hline 9 & Conflict with roommate/homemate & {$[2],[3],[5],[10],[15],[17],[18]$} \\
\hline 10 & $\begin{array}{l}\text { Fear of being an architect will not satisfy } \\
\text { expectations }\end{array}$ & {$[3],[16],[19]$} \\
\hline 11 & $\begin{array}{l}\text { Probability of not working as an architect because of } \\
\text { construction industry conditions }\end{array}$ & [3], [13], [19] \\
\hline 12 & Inadequate announcing of university activities & {$[6],[15],[19]$} \\
\hline 13 & $\begin{array}{l}\text { Inadequate announcing of architecture department } \\
\text { activities }\end{array}$ & {$[6],[18],[19]$} \\
\hline 14 & Lack of sport facilities on campus & {$[6],[15],[19]$} \\
\hline 15 & Changing social activities & {$[5],[8],[15]$} \\
\hline 16 & Lack of a psychological support unit on campus & {$[11][15],[19]$} \\
\hline 17 & Reserved behaviours of instructors & {$[3],[6],[15],[17],[18],[19]$} \\
\hline 18 & Instructors avoid communication & [3], [6], [15], [17], [18], [19] \\
\hline 19 & Instructors' discouraging criticism & {$[2],[7],[15],[17],[18],[19]$} \\
\hline 20 & Groupings in student societies & {$[2],[6],[19]$} \\
\hline 21 & Arguing with lecturers & {$[10],[18],[19]$} \\
\hline 22 & $\begin{array}{l}\text { The increased hours of architectural design studio } \\
\text { courses }\end{array}$ & [11], [14], [17], [18], [19] \\
\hline 23 & Overload of architectural design studio studies & [1], [11], [14], [17], [18], [19] \\
\hline 24 & Studying long hours outside of school hours & {$[11],[12],[17],[19]$} \\
\hline 25 & Changes in eating and sleeping habits & [5], [8], [11], [12], [17], [18], [19] \\
\hline 26 & Grade rating system at architectural design studios & [7], [11], [14], [17], [19] \\
\hline 27 & $\begin{array}{l}\text { Feeling anxiety when unable to reach academic } \\
\text { goals }\end{array}$ & [3], [4], [8], [9], [12], [17], [18], [19] \\
\hline 28 & Dissatisfaction with grades & {$[3],[8],[9],[10],[15],[17],[19]$} \\
\hline 29 & Thoughts of grades affecting future life & {$[3],[12],[16],[17]$} \\
\hline 30 & $\begin{array}{l}\text { My academic success is not enough to achieve } \\
\text { occupational dreams }\end{array}$ & {$[4],[9],[10],[12],[16],[17]$} \\
\hline 31 & Lack of concentration on course subjects & {$[12],[17],[19]$} \\
\hline 32 & Parental problems & {$[2],[3],[5],[10],[13],[17]$} \\
\hline 33 & Familial health problems & [13], [17] \\
\hline 34 & Probability of changing my career & {$[13],[18],[19]$} \\
\hline 35 & $\begin{array}{l}\text { Feeling incompetent to reach occupational dreams } \\
\text { because of financial problems }\end{array}$ & [2], [3], [8], [9], [10], [11], [16], [17], [18], [19] \\
\hline 36 & Excessive class assignments & [9], [11], [12], [15], [16], [17], [18], [19] \\
\hline 37 & Excessive teamwork & {$[9],[12],[17],[18]$} \\
\hline 38 & Short examination time & {$[2],[3],[8],[9],[11],[12],[15],[16],[17]$} \\
\hline 39 & Difficult examination questions & {$[2],[3],[8],[9],[10],[12],[15],[16],[17]$} \\
\hline 40 & Cannot arrive on time to courses & [5], [11], [19] \\
\hline 41 & Transportation problems reaching campus & {$[5],[18],[19]$} \\
\hline 42 & Waiting for long lines & {$[2],[5],[19]$} \\
\hline 43 & Lack of time for studying courses & {$[3],[6],[7],[8],[9],[12],[15],[17],[18]$} \\
\hline 44 & The size of the curriculum is excessive & [1], [7], [9], [11], [15], [16], [18], [19] \\
\hline
\end{tabular}

Table 1.

Stress indicators 


\begin{tabular}{lll}
\hline No. & Stress indicators & Reference \\
\hline 45 & Excessive amounts of materials and subjects & {$[2],[7],[8],[9],[15],[18],[19]$} \\
46 & Inappropriate evaluation techniques for grading & {$[6],[7],[17],[18]$} \\
47 & Insufficient education techniques & {$[2],[7],[19]$} \\
48 & Limited access to course materials & {$[2],[7],[10],[17]$} \\
49 & Inadequate amount of academic staff & {$[2],[10],[17],[18]$} \\
50 & Poor faculty-student relations & {$[2],[10],[14],[15],[17]$}
\end{tabular}

Notes: [1] Braaten (1964); [2] Zeidner (1992); [3] Abouserie (1994); [4] Gadzella (1994); [5] Ross et al. (1999); [6] Gizir (2005); [7] Bachman and Bachman (2006); [8] Robotham and Julian (2006); [9] Robotham (2008); [10] Shah et al. (2010); [11] Baqutayan (2011); [12] Sun et al. (2011); [13] Sohail (2013); [14] Ahrentzen and Anthony (1993); [15] Azila-Gbettor et al. (2015); [16] Bedewy and Gabriel (2015); [17] Hegenauer (2018); [18] Kirkpatrick (2018); [19] Obtained by interviews

Table 1.

into two septa according to the cut-off value chosen from the studies of Shah et al. (2010) and Amr et al. (2008), and this cut-off value was determined as 28. The upper two and lower two septa were ( 28 being the cut-off value) were labelled as "stressed" and "not stressed", respectively.

\subsection{Data collection and participants}

The sample of this research comprises first, second, third and fourth-year architecture students studying in the departments of architecture at Hasan Kalyoncu University and Balıkesir University during the spring/second semester of the 2018-2019 academic year. In particular, Hasan Kalyoncu University is a private university, whereas Balikesir University is a state university in Turkey. The questionnaire was simultaneously administered to all students enrolled in the architecture programmes of the two universities, and participation was voluntary.

In this study, there are two different architecture departments located in different cities that may include certain variables. Decreasing the number of variables is advantageous for evaluating the data, and to this, some criteria and limitations were determined before using the questionnaires. Before conducting the survey, all students were informed about the importance of the study and it was guaranteed giving information to participants about the stress level of total students at the end of the research. The questionnaires were administrated to 468 architecture students who were studying at the two different universities simultaneously during the spring/second semester from 01 April-30 May 2019. All questionnaires were conducted at the most crowded architecture design classes in both departments. Because of the application of questionnaires in the design classes, students used drawing tables whose styles and sizes were similar to those of furniture. The time of the day was another important criterion for conducting the survey. In the morning, during the first session of the day, just 15 min before starting the lessons, hardcopy questionnaires were delivered to students. The most crowded architecture design classes were examined for conducting surveys. In this procedure, a total of 459 completed questionnaires were returned, representing a response rate of $98.07 \%$.

The participants were 18-29 years old and included both males and females. A total of $233(50.8 \%)$ participants were 18-21 years of age, $211(46.0 \%)$ were $22-25$ years old and 15 $(3.2 \%)$ participants were 26-29 years old. Of the total participants, $234(51.0 \%)$ were females. The sample included $102(22.2 \%)$ freshmen, $95(20.7 \%)$ second-year students, 94 $(20.5 \%)$ third-year students and $168(36.6 \%)$ fourth-year students. The university type 
$\mathrm{OHI}$

46,2

288

representations consisted of $262(57.1 \%)$ students educated in a private university, and 197 $(42.9 \%)$ students educated in the state university.

\subsection{Analysing data}

The responses given by the participants were coded and analysed using the Statistical Package for Social Sciences (SPSS v. 22.0) and LISREL8.7.

Generally, SPSS is used to conduct various statistical tests, including reliability analysis and exploratory factor analysis (EFA).

According to several social scientists (Nunnally and Bernstein, 2007), the reliability should be measured to identify the internal consistency among questions present in a questionnaire while using the Likert scale. Using Likert-scale questions in this study, the Cronbach's alpha $(\alpha)$ coefficient was used to determine the statistical reliability and validity of the participants' responses. The $\alpha$ coefficient values range between 0 and 1 , where 0.7 represents the minimum acceptable reliability threshold (Cronbach, 1951; Tavakol and Dennick, 2011). To ensure the internal consistency, reliability analyses were conducted on questions according to their sections which are presented in Table 2.

All the values are viewed as acceptable, because both the alpha were above 0.6 , which is within the sufficient range of internal consistency for a study (Cronbach, 1951).

As a part of its main objective, identifying the underlying factor structure is important for this study. To achieve this aim, an EFA was used. There were 50 reliable stress indicators in the questionnaire that were entered into the SPSS software. To identify the main categories of the factors, the responses to the 50 items were subjected to EFA with a varimax rotation (eigenvalue $=1$ cut-off). The items with factor loadings greater than 0.4 were accepted as the main factors (Nunnally and Bernstein, 2007).

In the second part of the data analysis, a confirmatory factor analysis (CFA) was conducted on each stressor using the LISREL software.

CFA is a type of SEM that is used specifically for measurement models, that is, the relationships between the observed measures or indicators (e.g. test items, test scores, behavioural observation ratings) and latent variables or factors (Brown and Moore, 2012).

The structural equation models comprise two components: a hypothetical model and a structural model that concerns how well various exogenous variables measure as compared to latent variables. The hypothetical model integrates estimates of errors of measurement of exogenous variables and their intended latent variables within a structural equation model (Green, 1990). The structural model is the second constituent of the structural equation model. Unlike the standard regression models, these structural equation models can explicitly model direct, indirect or correlative effects. Emphasising an occurrence or process is the structural component of the structural equation models that allows researchers to derive essential assertions about the relationships between the mechanisms and latent variables. The structural component of the structural equation model is similar to the system of simultaneous regression models (Meyers et al., 2006).

To set up the final structural model, satisfying the requirement of the standard indices of model fit (such as t-statistics and R-squares for model equations) is necessary according to Molenaar et al. (2000). Otherwise, the findings may be raw and immature based upon

Table 2.

Reliability analyses of scales

Description

Stressors

Perceived stress scale
No. of items

Cronbach's alpha

50

14
0.874

0.792 
theoretical anticipations and former empirical and observed findings. A feasible model should be selected based on the recommended goodness-of-fit (GOF) measures, and the model that satisfies both the theoretical expectations and GOF is finally selected for the

SEM analysis (Molenaar et al., 2000). Therefore, in this study, the model was improved to enhance the fit to its recommended levels by using GOF measures.

To measure the adequacy of the model with respect to the relationship between the latent variables and the underlying standardised loadings of the measurement paths, the SEM analysis is usually a reasonable assessment method of the reliability measure.

The path coefficients through the variables are indicated in the SEM as follows:

- Effect size $<0.1$ indicates small effects.

- Approximately 0.3 denotes medium effects.

- A value $\geq 0.5$ represents large effects (Şimşek, 2007).

There is no certain rule in the literature about the lower bound value required for the path coefficient to be considered significant; however, a path coefficient above 0.1 is stated as satisfactory, and the ideal value is recommended to be above 0.2 (Chin, 1998; Lohmöller, 1989). The path coefficients equal to or above 0.4 and $t$-values of more than 2.58 were accepted to be significant at a $99.0 \%$ confidence level in the current study. According to the relationships among the stress factors, the main model was formed by using the SEM method (Figure 1).

\section{Results}

\subsection{Perceived stress level}

The mean PSS-14 score of the architecture students was 31.14 (SD = 8.44). Evaluating this value, using a cut-off value of 28.00 for the PSS-14, it was found that the architecture students had high levels of perceived stress.

The mean PSS score of the female students $(n=234)$ was $32.66(\mathrm{SD}=8.29)$, whereas that for the male students $(n=221)$ was $29.43(\mathrm{SD}=8.25)$. Based on an independent samples $t$-test, the gender was found to be significant $(p=0.00<0.05)$ according to the PSS score. The female students had significantly higher levels of perceived stress than their male peers.

The mean PSS-14 score of the students educated at the state university $(n=197)$ was 30.67 ( $\mathrm{SD}=8.17)$, whereas that of the students educated at the private university $(n=262)$ was 31.49 (SD = 8.63). Although architecture students educated at a private university have slightly higher reported levels of stress than the others, there is no statistically significant relationship with the type of university $(\phi=0.17>0.05)$. This finding demonstrates that, architecture students show high stress levels regardless of the type of university.

\subsection{Underlying factors that affect the stress level of architecture students - exploratory factor analysis-principled stressors}

As the main objective of this study, identifying the underlying factor structure is important for this study. An EFA was conducted based on the responses to the 50 items with the varimax rotation (eigenvalue $=1$ cut-off) to determine the main categories of stressors. The items with factor loadings greater than 0.4 were accepted as the principle stressors (Nunnally and Bernstein, 2007). As can be seen, majority of the stressors load onto appropriate factors. Six items (stress indicator numbers 4-9 indicated in italics in Table 1) were removed from the questionnaire as their factor loadings were smaller than 0.4. Finally, the EFA results of 44 items with their Cronbach's alpha coefficient reliabilities are 
$\mathrm{OHI}$

46,2

290

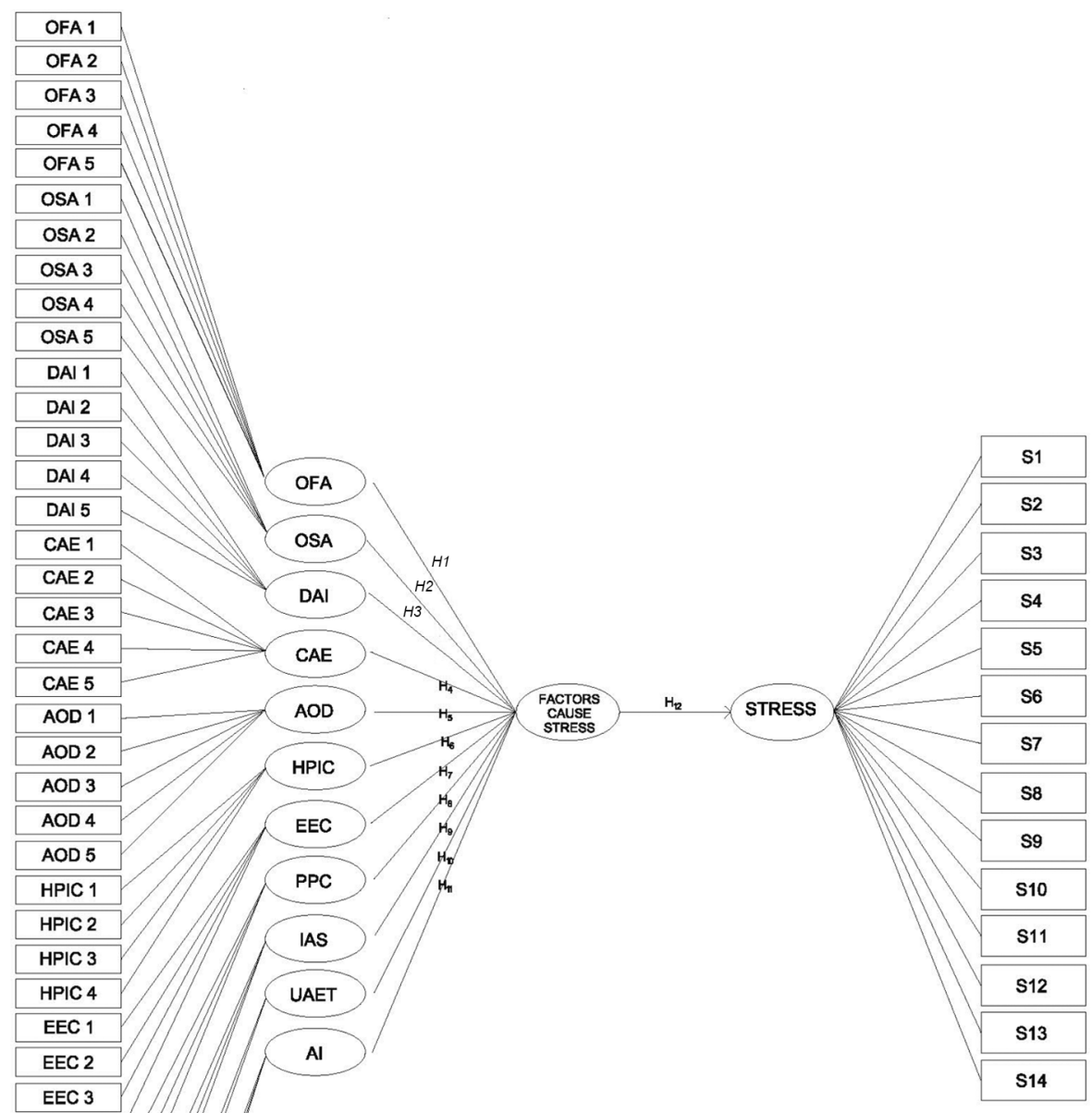

Figure 1.

Hypothetical model of the factors affecting the stress of

architectural students

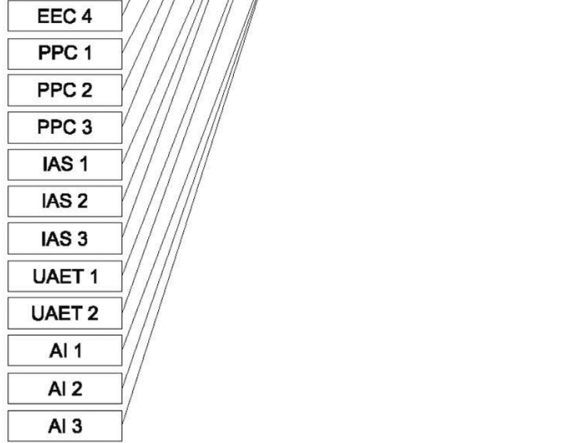


summarised in Table 3. Cronbach' alpha for each scale (reported as Table 3) ranges from 0.700 to $0.831(\alpha>0.600)$, indicating good to excellent scale reliability.

The Kaiser-Meyer-Olkin values and Barlett tests of sphericity indicate the suitability of

the data set for EFA, which suggests that the data set of the current study is appropriate for factor analysis (Pallant, 2001). The principal component analysis and varimax rotation were used as the factor extraction and rotation methods, respectively. The results indicated an 11factor solution, which accounted for $61.4 \%$ of the total variance. Each factor was interpreted, labelled and coded based on the stressors that made up the group as follows:

- Factor 1: Occupational future anxiety (OFA).

- Factor 2: Obstacles to social activities (OSA).

- Factor 3: Demotivating approach of instructors (DAI).

- Factor 4: Different characteristics of architectural education (CAE).

- Factor 5: Anxiety that one cannot realise occupational dreams (AOD).

- Factor 6: Health problems of family members and inconstant vocational career (HPIC).

- Factor 7: Examination-course challenges (ECC).

- Factor 8: Poor physical conditions (PPC).

- Factor 9: Intensive academic schedule (IAS).

- Factor 10: Unusual assessment and evaluation techniques of courses (UAET).

- Factor 11: Academic inadequacy (AI).

\subsection{Stressor interrelationships}

The stressor interrelationships were analysed using correlation analysis. The intercorrelations within the 11 stressors are given in Table 4. Remarkable positive correlations (significant at $p \leq 0.01$ ) are found between:

- OSA and PPC (0.400);

- DAI and AI (0.466);

- CAE and IAS (0.421);

- AOD and ECC (0.441);

- $\quad$ ECC and IAS (0.437);

- PPC and IAS (0.414); and

- UAET and AI (0.522).

\subsection{Analysis of the structural equation model}

The framework of the current research was provided by the above-mentioned literature review. A conceptual model of the effects of main stressors on the stress level is proposed and shown in Figure 1. Each path of the model represents a hypothetical relationship between a pair of constructs.

It is hypothesised that the factors that cause stress (OFA, OSA, DAI, CAE, AOD, HPIC, ECC, PPC, IAS, UAET and AI) affect the stress level of the architecture students.

To examine the effects of these 11 main stressors on the stress levels, the following 12 hypotheses were established as follows (paths in Figure 1): 
$\mathrm{OHI}$

46,2

\begin{tabular}{|c|c|c|c|c|c|}
\hline Factors & Coded as & $\begin{array}{l}\text { Stress indicator } \\
\text { no. }\end{array}$ & $\begin{array}{c}\text { Factor } \\
\text { loadings }\end{array}$ & $\begin{array}{c}\% \text { of } \\
\text { variance }\end{array}$ & $\begin{array}{l}\text { Cronbach's } \\
\text { alpha }\end{array}$ \\
\hline \multirow[t]{5}{*}{ Factor 1 (OFA) } & OFA 1 & 1 & 0.828 & \multirow[t]{5}{*}{7.109} & \multirow[t]{5}{*}{0.809} \\
\hline & OFA 2 & 2 & 0.825 & & \\
\hline & OFA 3 & 3 & 0.732 & & \\
\hline & OFA 4 & 10 & 0.630 & & \\
\hline & OFA 5 & 11 & 0.509 & & \\
\hline \multirow[t]{5}{*}{ Factor 2 (OSA) } & OSA 1 & 12 & 0.802 & \multirow[t]{5}{*}{6.862} & \multirow[t]{5}{*}{0.802} \\
\hline & OSA 2 & 13 & 0.792 & & \\
\hline & OSA 3 & 14 & 0.701 & & \\
\hline & OSA 4 & 15 & 0.646 & & \\
\hline & OSA 5 & 16 & 0.531 & & \\
\hline \multirow[t]{5}{*}{ Factor 3 (DAI) } & DAI 1 & 17 & 0.790 & \multirow[t]{5}{*}{6.352} & \multirow[t]{5}{*}{0.761} \\
\hline & DAI 2 & 18 & 0.778 & & \\
\hline & DAI 3 & 19 & 0.684 & & \\
\hline & DAI 4 & 20 & 0.545 & & \\
\hline & DAI 5 & 21 & 0.465 & & \\
\hline \multirow[t]{5}{*}{ Factor 4 (CAE) } & CAE 1 & 22 & 0.804 & \multirow[t]{5}{*}{6.322} & \multirow[t]{5}{*}{0.757} \\
\hline & CAE 2 & 23 & 0.750 & & \\
\hline & CAE 3 & 24 & 0.745 & & \\
\hline & CAE 4 & 25 & 0.500 & & \\
\hline & CAE 5 & 26 & 0.404 & & \\
\hline \multirow{5}{*}{ Factor 5 (AOD) } & AOD 1 & 27 & 0.808 & \multirow[t]{5}{*}{6.212} & \multirow[t]{5}{*}{0.777} \\
\hline & AOD 2 & 28 & 0.732 & & \\
\hline & AOD 3 & 29 & 0.684 & & \\
\hline & AOD 4 & 30 & 0.589 & & \\
\hline & AOD 5 & 31 & 0.453 & & \\
\hline \multirow[t]{4}{*}{ Factor 6 (HPIC) } & HPIC 1 & 32 & 0.801 & \multirow[t]{4}{*}{5.689} & \multirow[t]{4}{*}{0.718} \\
\hline & HPIC 2 & 33 & 0.776 & & \\
\hline & HPIC 3 & 34 & 0.562 & & \\
\hline & HPIC 4 & 35 & 0.512 & & \\
\hline \multirow[t]{4}{*}{ Factor 7 (ECC) } & $\mathrm{ECC} 1$ & 36 & 0.792 & \multirow[t]{4}{*}{5.260} & \multirow[t]{4}{*}{0.728} \\
\hline & $\mathrm{ECC} 2$ & 37 & 0.688 & & \\
\hline & ECC 3 & 38 & 0.638 & & \\
\hline & $\mathrm{ECC} 4$ & 39 & 0.580 & & \\
\hline Factor 8 (PPC) & PPC 1 & 40 & 0.804 & 5.242 & 0.831 \\
\hline & PPC 2 & 41 & 0.772 & & \\
\hline & PPC 3 & 42 & 0.738 & & \\
\hline Factor 9 (IAS) & IAS 1 & 43 & 0.717 & 4.238 & 0.742 \\
\hline & IAS 2 & 44 & 0.702 & & \\
\hline & IAS 3 & 45 & 0.581 & & \\
\hline Factor 10 (UAET) & UAET 1 & 46 & 0.719 & 4.121 & 0.700 \\
\hline & UAET 2 & 47 & 0.644 & & \\
\hline Factor 11 & AI 1 & 48 & 0.710 & 3.993 & 0.710 \\
\hline (AI) & $\mathrm{AI} 2$ & 49 & 0.569 & & \\
\hline & AI 3 & 50 & 0.490 & & \\
\hline Total explained va & & & 61.400 & & \\
\hline Kaiser-Meyer-Olk & (MO) value & & 0.871 & & \\
\hline Barlett's test of & Approx. C & uare & & & $7,882.337$ \\
\hline sphericity & $\mathrm{df}$ & & & & 946 \\
\hline & $p$ & & & & 0.000 \\
\hline
\end{tabular}

Table 3.

Exploratory factor analysis of stressors
Approx. Chi-square

$p$
46

0.000 


\begin{tabular}{|c|c|c|c|c|c|c|c|c|c|c|c|c|}
\hline & OFA & OSA & DAI & $\mathrm{CAE}$ & $\mathrm{AOD}$ & HPIC & $\mathrm{ECC}$ & PPC & IAS & UAET & $\mathrm{AI}$ & $\begin{array}{l}\text { factors } \\
\text { fal suress }\end{array}$ \\
\hline OFA & 1 & & & & & & & & & & & \\
\hline OSA & $0.242 * *$ & 1 & & & & & & & & & & \\
\hline DAI & $0.305^{* *}$ & $0.376^{* *}$ & 1 & & & & & & & & & \\
\hline CAE & $0.309 * *$ & $0.348^{* *}$ & $0.273^{* *}$ & 1 & & & & & & & & \\
\hline $\mathrm{AOD}$ & $0.337 * *$ & $0.289 * *$ & $0.278^{* * *}$ & $0.340^{\text {** }}$ & 1 & & & & & & & \\
\hline HPIC & $0.365^{* *}$ & $0.261^{* *}$ & $0.391^{* *}$ & $0.186^{* *}$ & $0.376^{* *}$ & 1 & & & & & & 293 \\
\hline $\mathrm{ECC}$ & $0.184^{* * *}$ & $0.275^{* *}$ & $0.288^{* *}$ & $0.379^{* *}$ & $0.441^{* *}$ & $0.279 * *$ & 1 & & & & & \\
\hline PPC & $0.282^{* * *}$ & $0.400^{* * *}$ & $0.344^{* *}$ & $0.377^{* *}$ & $0.323^{* *}$ & $0.220^{* *}$ & $0.380^{* *}$ & 1 & & & & \\
\hline IAS & $0.262^{* * *}$ & $0.277^{* *}$ & $0.259^{* *}$ & $0.421^{* *}$ & $0.381^{* *}$ & $0.248^{* *}$ & $0.437^{* *}$ & $0.414^{* *}$ & 1 & & & \\
\hline UAET & $0.323 * *$ & $0.353^{* *}$ & $0.370^{* *}$ & $0.336^{* *}$ & $0.163^{* *}$ & $0.247^{* * *}$ & $0.271^{* *}$ & $0.357^{* *}$ & $0.334 * *$ & 1 & & \\
\hline AI & $0.378 * *$ & $0.383^{* *}$ & $0.466^{* *}$ & $0.325^{* *}$ & $0.264^{* *}$ & $0.327^{* *}$ & $0.261^{* *}$ & $0.388^{* *}$ & $0.373^{* *}$ & $0.522 * *$ & 1 & $\begin{array}{r}\text { Table } 4 \\
\text { Correlation amongst }\end{array}$ \\
\hline \multicolumn{12}{|c|}{ Note: **Correlation is significant at the 0.01 level (two-tailed) } & stressors \\
\hline
\end{tabular}

H1. OFA has a negative effect on the architecture students' stress levels.

H2. OSA has a negative effect on the architecture students' stress levels.

H3. DAI has a negative effect on the architecture students' stress levels.

H4. CAE have a negative effect on the architecture students' stress levels.

H5. AOD has a negative effect on the architecture students' stress levels.

H6. HPIC have a negative effect on the architecture students' stress levels.

H7. ECC have a negative effect on the architecture students' stress levels.

H8. PPC have a negative effect on the architecture students' stress levels.

H9. IAS has a negative effect on the architecture students' stress levels.

H1O. UAET have a negative effect on the architecture students' stress levels.

H11. AI has a negative effect on the architecture students' stress levels.

H12. A total of 11 stress factors (OFA, OSA, DAI, CAE, AOD, HPIC, ECC, PPC, IAS, UAET and AI) have a negative effect on the perceived stress levels of the architecture students.

\subsection{Results of structural equation modelling and hypothesis testing}

The validation of the structural model was carried out using LISREL 8.71 software. The paths of the model were measured according to the different signs, sizes and statistical significances of the path coefficients among the variables. The higher the path coefficient, the stronger is the relationship between the independent and dependent constructs of a path.

The significance of the hypothesised associations was examined by evaluating the significance of the $t$-values. Tables 5 and 6 (also see Figure 2) summarise all the parameters used in the validation process of the model.

OFA1, OFA2 and OFA3 represent the main indicators under the OFA construct, and the critical indicator of OSA is OSA1. Additionally, DAI1 is the most important indicator of DAI, and AOD1 is a critical indicator of AOD. Finally, PPC1 represents the most reliable indicator of the PPC construct. 
$\mathrm{OHI}$

46,2

294

In the current study, the model was improved to enhance the fit to its recommended levels using the GOF measures, as shown in Table 5. The initial hypothesised model (Figure 1) was analysed using LISREL 8.71 software. It was seen that the GOF measures of the final model could achieve the recommended levels after the elimination of five items from the PSS-14 within two trials.

Associated with hypothesised model shown in Figure 1, the final structural equation model is presented in Figure 2 along with the standardised path coefficients of the structural paths.

It is clearly seen that final model developed for the architecture students' stress fits based on the required GOF measures could perform satisfactorily. Both the GOF index (GFI) value of 0.95 and the ratio of $\chi^{2}$ /degrees of freedom of 2.10 are within the acceptable range. The root mean square error of approximation (RMSEA) value of 0.04 at $p<0.05$ shows that the final model cannot be rejected with a high level of confidence (Table 5).

In addition, other necessary indicators such as the comparative fit index $(\mathrm{CFI}=0.95)$ and the normed fit index $(\mathrm{NFI}=0.95)$ contribute to the reason for accepting the fit between the data and the measurement model (Molenaar et al., 2000).

Table 6 summarises the hypothetical paths and assumed effects, standardised path coefficients and the signs of the hypothesised paths. Using the $t$-test values, the

\section{Table 5.}

Results of GOF measures

\begin{tabular}{lccc}
\hline $\begin{array}{l}\text { Goodness-of-fit } \\
\text { (GOF) measure }\end{array}$ & $\begin{array}{c}\text { Recommended level } \\
\text { of GOF measure }\end{array}$ & $\begin{array}{c}\text { Initial structural } \\
\text { equation model }\end{array}$ & $\begin{array}{r}\text { Final structural } \\
\text { equation model }\end{array}$ \\
\hline$\chi^{2} / \mathrm{df}$ & $0 \leq \chi^{2} / \mathrm{df} \leq 3$ & 5.08 & 2.10 \\
GFI & $095 \leq \mathrm{GFI} \leq 1.00$ & 0.67 & 0.95 \\
AGFI & $0,95 \leq \mathrm{AGFI} \leq 1.00$ & 0.61 & 0.95 \\
RMSEA & $0 \leq \mathrm{RMSEA} \leq 0.05$ & 0.14 & 0.04 \\
CFI & $0.95 \leq \mathrm{CFI} \leq 1.00$ & 0.81 & 0.95 \\
NFI & $0.95 \leq \mathrm{NFI} \leq 1.00$ & 0.78 & 0.95
\end{tabular}

Source: Adapted from Molenaar et al. (2000)

Table 6.

Standardised coefficient estimates ( $p$-value) of the final structural equation model

\begin{tabular}{|c|c|c|c|c|c|}
\hline $\begin{array}{l}\text { Hypothetical paths and } \\
\text { expected influences }\end{array}$ & $\begin{array}{c}\text { Path } \\
\text { coefficienta }\end{array}$ & $\begin{array}{l}t \text {-Value } \\
\text { (one-tail) }\end{array}$ & Sig. $(p)$ & $R^{2}$ & Interpretation \\
\hline$H 1: \mathrm{OFA} \rightarrow \mathrm{GS}$ & +0.53 & 9.58 & 0.00 & 0.28 & Supported \\
\hline$H 2: \mathrm{OSA} \rightarrow \mathrm{GS}$ & +0.58 & 11.06 & 0.00 & 0.33 & Supported \\
\hline$H 3: \mathrm{DAI} \rightarrow \mathrm{GS}$ & +0.61 & 10.61 & 0.00 & 0.37 & Supported \\
\hline H4: $\mathrm{CAE} \rightarrow \mathrm{GS}$ & +0.68 & 10.36 & 0.00 & 0.46 & Supported \\
\hline$H 5: \mathrm{AOD} \rightarrow \mathrm{GS}$ & +0.60 & 10.30 & 0.00 & 0.36 & Supported \\
\hline$H 6: \mathrm{HPIC} \rightarrow \mathrm{GS}$ & +0.63 & 8.34 & 0.00 & 0.40 & Supported \\
\hline$H 7: \mathrm{ECC} \rightarrow \mathrm{GS}$ & +0.62 & 9.84 & 0.00 & 0.39 & Supported \\
\hline H8: $\mathrm{PPC} \rightarrow \mathrm{GS}$ & +0.68 & 12.93 & 0.00 & 0.46 & Supported \\
\hline H9: IAS $\rightarrow$ GS & +0.72 & 10.66 & 0.00 & 0.52 & Supported \\
\hline H1O: UAET $\rightarrow$ GS & +0.71 & 10.42 & 0.00 & 0.50 & Supported \\
\hline$H 11: \mathrm{AI} \rightarrow \mathrm{GS}$ & +0.80 & 10.03 & 0.00 & 0.64 & Supported \\
\hline H12: GS $\rightarrow$ PS & +0.47 & 8.46 & 0.00 & 0.22 & Supported \\
\hline
\end{tabular}

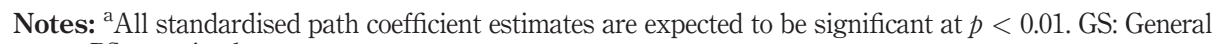
stress; PS: perceived stress 


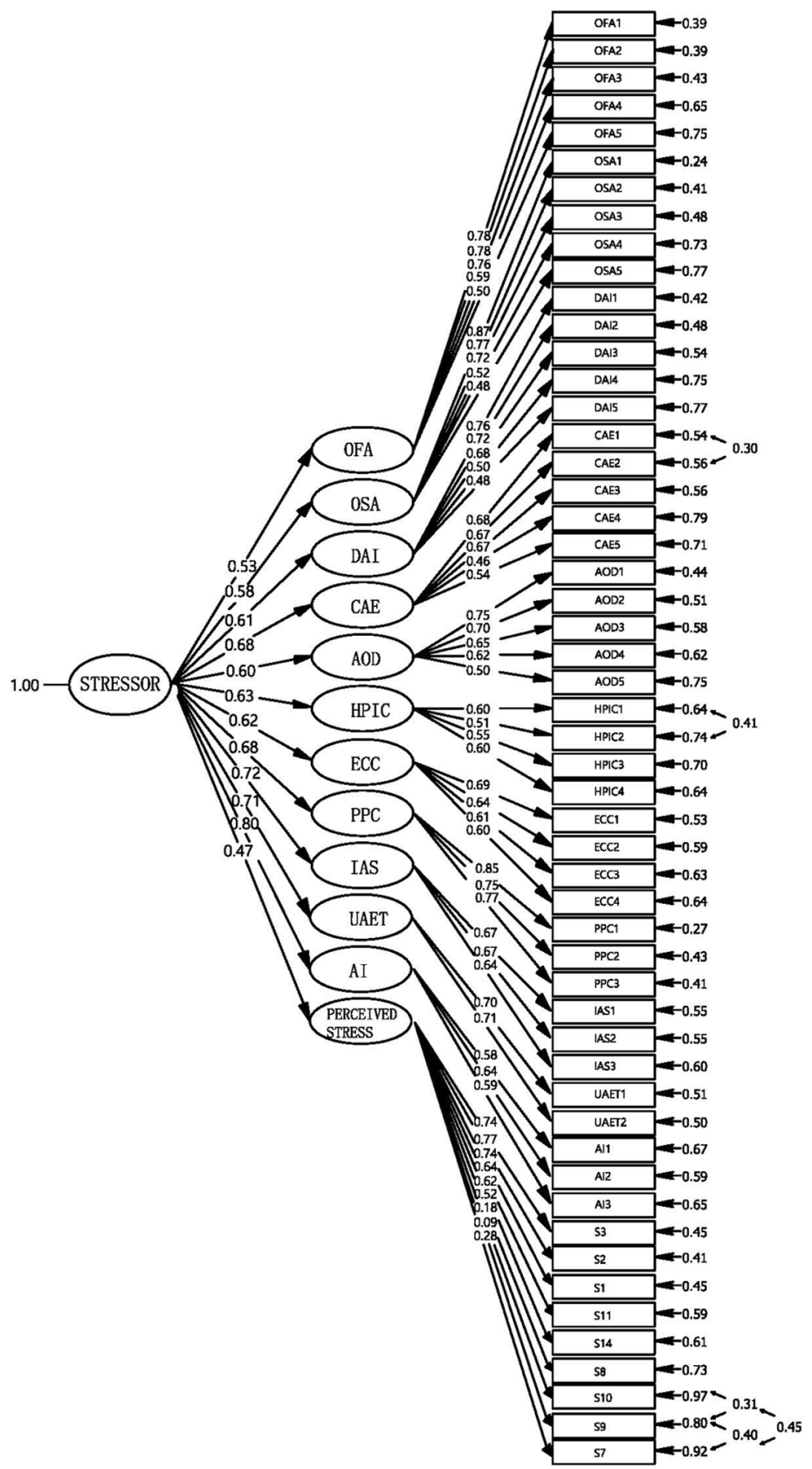

Critical stress factors

Figure 2.

Final structural equation model of factors influencing architecture students' 
$\mathrm{OHI}$

46,2

significance of the path coefficients was analysed. To determine the one-way impacts of one factor over another, the one-tailed significance $(p<0.01)$ method is used (Field, 2005).

As seen in Figure 2 and Table 6, all 12 hypotheses could be proved at the acceptable significance level of $p<0.01$, and $t$-values $>2.58$, which indicate a $99.0 \%$ confidence level. Table 6 indicates that $\mathrm{AI}(0.80)$ has the most potential effect on the students' stress, followed by IAS (0.72), UAET (0.71), CAE and PPC (0.68). In addition, HPIC (0.63), ECC (0.62), DAI (0.61), AOD (0.60), OSA (0.58) and OFA (0.53) had statistically significant effects on the students' stress. It is remarkable that all stress factors that comprise the general stress affect the students' perceived stress by 0.47 . These results fully satisfy all the hypotheses stated before.

\section{Discussion}

The findings in the literature regarding the stress level and sources of stress are mostly associated with students studying in departments other than architecture. Therefore, the principles and issues determined in the current study will be useful in understanding the context for learning within the architectural environment.

The first important finding of this study is that female architecture students show higher levels of perceived stress than their male peers. Stroud et al. (2002) claimed that males are more inclined to be central than female ones. On the other hand, women appear more physiologically reactive to social rejection challenges, but men react more to achievement challenges. Gadzella (2002) stated that female students respond in more physiological, emotional and behavioural manners. Moreover, female students give different and inconsistent reactions to stressors, whereas male students were found to be less anxious about stress sources. Abouserie (1994) stated that female university students are more stressed than males. Therefore, this finding is consistent with results of previous research.

The current study demonstrates that according to the final SEM results, 11 key stressors influence and significantly impact the architecture students' stress levels.

"AI" is determined as the most important factor that influences the perceived stress level of architecture students. According to results of the study by Ostwald and Williams' (2008), the most challenging problem architectural education faces is inadequate number of staff level. Because the academic salary levels, conditions and sessional staff rates of pay are less attractive than those of industries, filling gaps in the architecture school's profile is generally difficult in Turkey, similar to the case of Australia (Ostwald and Williams, 2008). The poor student-faculty interaction is another significant determinant of the AI. The results of the RIBA, 2017 survey show that $42 \%$ students reported the "insensitivity of a lecturer or other teacher" as a trigger for architecture students' mental distress.

"IAS" is found to be the second most important factor affecting general stress levels of the architecture students. Unlike those of other departments, the architecture curriculum is more intensive (Bachman and Bachman, 2006; Kirkpatrick, 2018), which signifies a greater workload. In particular, workload issues include numerous exams, meeting assessment deadlines, increased theoretical course work, long hours spent on projects in studios and a competitive atmosphere among peers. Because of these issues, the architecture students feel oppressed. Compared with the findings by Bachman and Bachman (2006), the time constraint composing of three components (studio workload, studio study time and job hours) was also reported to be a key factor that affected architecture students' stress levels. Hegenauer (2018) emphasised 
that the huge number of projects and exams can lead to sense of oppression among many students because of the time required to accomplish the heavy workload. Xie et al. (2019) reported that heavy workloads and culture of working hard are the main

sources of stress for architecture students. The findings of these three studies that were conducted among architecture students support the results of this study.

"UAET"; "CAE" and "ECC" are determined to be the other significant factors that affect the general stress levels of architecture students. The professional degree plan of architectural education is filled with diverse and challenging topics, including history, technology, human factors, theory, urban planning, issues of professional practise and design. The focal experience of design study is situated at the curriculum's epicentre, which is typically taken every semester for four or five credits.

Architecture students foresee to specialise and overcome architectural challenges in design studios, whose curriculums anticipate the learning and assimilation of the main topics of architecture subjects. The design studio is principally an autonomously administrated experience using tacit knowledge and intuitive talent. In particular, students are assigned a design task at the beginning of each semester. Architecture students need to construct their design and address the problems creatively (Yunyan et al., 2009). Each studio class is conducted with a small group of students (max. of 15 students) and led by a tutor who provides personalised feedback. During the design process, students can have regular one-on-one discussions with their studio tutors, and this generally takes $8 \mathrm{~h}$ per week.

Periodic reviews take the form of public presentations and are usually given the ominous title of "jury" (Anthony, 1991). Every one or two months, design juries are arranged in which students present their work and receive critiques from tutors and, sometimes, external jury members. Finally, the studio is inherently concerned with indeterminate problems, for which there are no singular objectively correct solutions. These indeterminacies are what Schön (1985) has termed the "wicked problems" of design. Students spend large amounts of resources such as effort, skills and time because of the specific characteristics (autonomous, open-ended, highly motivated and personally relevant) of design studios. During the studio process, architecture students are obligated to defend their designs against the tutors' critiques. Additionally, sometimes, they encounter several difficulties when responding to instructors' criticism and correction. According to Xie et al. (2019) and Rauf et al. (2020), critique of tutor's is important source of stress for architecture students. Furthermore, some students behave recklessly when the tutors critique them. It is assumed that these kinds of behaviours may be predictors of cynicism, which is an important determinant of burnout. Several studies emphasise that increased levels of stress can cause burnout (Leiter and Maslach, 1988; Maslach, 1993). According to Maslach (1993), there are three dimensions of burnout: exhaustion, cynicism and inefficacy. Leiter and Maslach (1988) proposed that exhaustion occurs first, followed by cynicism as a coping strategy for exhaustion, thereby leading to inefficacy. Considering the overall results, it is remarkable that UAET is a remarkable stress factor for architecture students owing to the characteristics of architectural education.

Another remarkable finding of this study is that "DAI" is an important factor that affects the general stress levels of architecture students. This finding is consistent with that of the study done by Kirkpatrick (2018). According to her, there are three main types of pressures students face in architecture schools: negative interactive relations with lecturers and tutors, anticipations and the workload. Consistent with 
$\mathrm{OHI}$

46,2

this study's findings, half of the architecture students state that their school provides lecturers and tutors having very limited education or none at all on how to communicate with their students. Their instructors "show empathy" but "do not have sufficient training in supporting students".

PPC is another factor that influences architecture students' stress levels. This finding is similar to that of Lin's (2012) study, where it was stated that the physical spaces and atmosphere in which student learning takes place have a significant effect on students' learning abilities. In particular, spaces and policies that are not conducive to learning have negative impacts on students' academic successes (Kater, 2017).

\section{Conclusion and recommendations}

Unlike other disciplines, architectural education has a different character. Architectural education has its own specifications, and it is distinct from both the practice of architecture and the education of other disciplines. Therefore, the structure of the education brings different stressors. Numerous studies have been published on factors affecting university and college students' stress level. However, there is not any research on stressors and critical stress factors on architecture students.

In this research, different and various stressors - including individual, academic, interpersonal relation and environmental - have been identified in connection with architecture students and architectural education.

From the findings of the research reported in this study, the following conclusions are made:

- Architecture students had high levels of stress.

- Female architecture students' stress level is higher than the male peers'.

- Type of the university is not determinant of architecture students' stress level.

- Architecture students' general stress levels are influenced by 11 remarkable factors, out of which the most significantly affecting factors are AI, IAS and UAET.

The following are recommended to decrease the architecture students' stress:

- restructuring the architectural education programme; and

- providing training to instructors on pedagogical formation about effective communication with students.

The workload of the architecture students may be reduced by reconstituting the architecture curriculum, which could benefit the students' well-being, although it should be noted that probably an improvement of the whole architectural education system is needed. This reconstitution can improve and augment the efficacy of the workload. The more practicebased learning approaches may be imparted after modification, and transforming the content of some modules may contribute to reducing the stress because of coinciding subjects.

The programme reconstitution is a significant viewpoint that should be handled; however, this would require remarkable improvement in the education system to successfully implement it. Educating instructors and students can make it possible to overcome stress, avoid mental health problems from arising and enable a more effective and open communication, which would be a better action for the near future. 
Compulsory education concentrated on how to support and communicate with students could be exploited by the instructors of architecture schools for training students regarding their own mental health and well-being. The importance of the issues confronted by students could be notified and strengthened, and a "positive" pedagogical approach could be gained by this education. Topics to concentrate on could involve the following: using positive language in tutorials, critics or reviews rather than demotivating comments, not supporting being all-nighters and other unhealthy habits, being open about their anticipations of students and the amount of factors time that should be spent on tasks.

The current study has some limitations when applying the questionnaires (e.g. to different architecture departments, season/semester of education year, the type of course, furniture size and style, time of day, etc.). Further research may limit the level of sound, size of classroom/studio and it may diversify the number of architectural departments. In addition, the structural model of the current study has a good fit; further studies may look into mediators between the social cultural values and stress.

For future studies, the effect of different educational technologies on architecture students' stress level may be investigated. The current research was conducted at second semester. Determining the difference of stress level between first and second semesters of architectural education may be a new research subject for future researches.

As mentioned above, stress has several effects, such as burnout, depression and turnover. What kind of consequences result from these stressors and stress levels of architecture students may be another topic of research for forthcoming/future studies.

\section{References}

Abouserie, R. (1994), "Sources and levels of stress in relation to locus of control and self esteem in university students", Educational Psychology, Vol. 14 No. 3, pp. 323-330.

Ahmed, Z. and Julius, S.H. (2015), "Academic performance, resilience, depression, anxiety and stress among women college students", Indian Journal of Positive Psychology, Vol. 6 No. 4, pp. 367-370.

Ahrentzen, S. and Anthony, K. (1993), "Sex, stars, and studios: a look at gendered educational practices in architecture", Journal of Architectural Education, Vol. 47 No. 1, pp. 11-29.

Amr, M., Gilany, A.H. and El-Hawary, A. (2008), "Does gender predict students' stress in mansoura, Egypt?”, Medical Education Online, Vol. 13 No. 1, pp. 1-7.

Anthony, K.H. (1991), Design Juries on Trial: The Renaissance of the Design Studio, Van Nostrand Reinhold, New York, NY.

Azila-Gbettor, E.M., Atatsi, E.A., Danku, L.S. and Soglo, N.Y. (2015), "Stress and academic achievement: empirical evidence of business students in ghanaian polytechnic", International Journal of Research in Business Studies and Management, Vol. 2 No. 4, pp. 78-98.

Bachman, L. and Bachman, C. (2006), "Student perceptions of academic workload in architectural education”, Journal of Architectural and Planning Research, Vol. 23 No. 4, pp. 271-304.

Baqutayan, M.S. (2011), "Studio stress", International Journal of Innovation, Management and Technology, Vol. 2 No. 4, pp. 295-300.

Baum, A., Singer, J.E. and Baum, C.S. (1981), "Stress and the environment", Journal of Social Issues, Vol. 37 No. 1, pp. 4-35.

Bedewy, D. and Gabriel, A. (2015), "Examining perceptions of academic stress and its sources among university students: the perception of academic stress scale", Health Psychology Open, Vol. 2 No. 2. 
$\mathrm{OHI}$

46,2

Bowen, P., Edwards, P. and Lingard, H. (2013), "Workplace stress among construction professionals in South Africa", Engineering, Construction and Architectural Management, Vol. 20 No. 6, pp. 620-635.

Braaten, L.J. (1964), “A psychologist looks at the teaching of architecture”, Journal of Architectural Education, Vol. 19 No. 1, pp. 5-9.

Brown, T.A. and Moore, M.T. (2012), "Confirmatory factor analysis", Hoyle, R.H. (Ed.), Handbook of Structural Equation Modeling, The Guilford Press. New York, NY, pp. 361-379.

Chan, I.Y., Leung, M.Y. and Yuan, T. (2014), "Structural relationships between cultural values and coping behaviours of professionals in the stressful construction industry", Engineering, Construction and Architectural Management, Vol. 21 No. 2, pp. 133-151.

Chin, W.W. (1998), "Issues and opinion on structural equation modelling", MIS Quarterly, Vol. 22 No. 1, pp. 7-16.

Cohen, S., Kamarck, T. and Mermelstein, R. (1989), "A global measure of perceived stress", Journal of Health and Social Behavior, Vol. 24 No. 4, pp. 385-396.

Cronbach, L.J. (1951), "Coefficient alpha and the internal structure of tests", Psychometrika, Vol. 16 No. 3, pp. 297-334.

Cuff, D. (1991), Architecture: The Story of Practice, MIT Press, Cambridge.

Elias, H., Ping, W.S. and Abdullah, M.C. (2011), "Stress and academic achievement among undergraduate students in universiti putra Malaysia”, Procedia - Social and Behavioral Sciences, Vol. 29, pp. 646-655.

Field, A. (2005), Discovering Statistics Using SPSS, Sage, London.

Fridlander, L., Reid, J.G., Shupak, N. and Cribbie, R. (2007), "Social support, self-esteem, and stress as predictors of adjustment to university among first-year undergraduates", Journal of College Student Development, Vol. 48 No. 3, pp. 259-274.

Gadzella, B.M. (1994), "Student-life stress inventory: identification of and reactions to stressors", Psychological Reports, Vol. 74 No. 2, pp. 95-402.

Gadzella, B.M. and Baloglu, M. (2001), "Confirmatory factor analysis and internal consistency of the student-life stress inventory", Journal of Instructional Psychology, Vol. 28 No. 2, pp. 84-94.

Gadzella, B.M., Stephens, R. and Baloglu, M. (2002), "Prediction of educational psychology course grades by age and learning style scores", College Student Journal, Vol. 36 No. 1, pp. $62-69$.

Gizir, C.A. (2005), "Orta doğu teknik üniversitesi son sinıf öğrencilerinin problemleri üzerine bir çalışma”, Mersin Üniversitesi Eğitim Fakültesi Dergisi, Vol. 1 No. 2, pp. 196-213.

Green, P.J. (1990), "On use of the EM algorithm for penalized likelihood estimation", Journal of the Royal Statistical Society: Series B (Methodological), Vol. 52 No. 3, pp. 443-452.

Harvey, L., Drew, S. and Smith, M. (2006), The First Year Experience: A Review of Literature for the Higher Education Academy, The Higher Education Academy, New York, NY.

Hegenauer, J.S. (2018), "Stress, depression, and anxiety in undergraduate engineering and architecture students", American Society for Engineering Education Northeast Section Conference, University of Hartford, Hartford, CT, 27-28 April, pp. 1-6.

Jessel, E. (2018), "Student survey: only the rich need apply to study architecture", Architects Journal, Vol. 1, pp. 10-14.

Kater, S.T. (2017), "Community college faculty conceptualizations of shared governance: shared understandings of a sociopolitical reality", Community College Review, Vol. 45 No. 3, pp. 234-257.

Kirkpatrick, M. (2018), "Mental well being and the architecture students", available at: https://absnet. org.uk/system/files/Dissertation\%20-\%20Melissa \%20Kirkpatrick.pdf (accessed 11 May 2020). 
Lazarus, R.S. and Cohen, J.B. (1977), "Environmental stress", Human Behavior and Environment, Springer, Boston, MA, pp. 89-127.

Leiter, M.P. and Maslach, C. (1988), “The impact of interpersonal environment on burnout and organizational commitment", Journal of Organizational Behavior, Vol. 9 No. 4, pp. 297-308.

Leung, M.Y., Chan, Y.S.I. and Dongyu, C. (2011), "Structural linear relationships between job stress, burnout, physiological stress, and performance of construction project managers", Engineering, Construction and Architectural Management, Vol. 18 No. 3, pp. 312-328.

Lin, Y. (2012), "Life experiences of dissatisfied science and engineering graduate students in Taiwan", College Student Journal, Vol. 46 No. 1, pp. 51-66.

Lohmöller, J.B. (1989), Latent Variable Path Modelling with Partial Least Squares, Physica-Verlag, Heidelberg.

Lumsden, D.P. (1981), "Is the concept of 'stress' of any use, anymore", Contributions to Primary Prevention in Mental Health: Working Papers: Canadian Mental Health Association. Toronto.

Majumdar, B. and Ray, A. (2010), "Stress and coping strategies among university students: a phenomenological study", Indian Journal of Social Science Researches, Vol. 7 No. 2, pp. 100-111.

Maslach, C. (1993), "Burnout: a multidimensional perspective", in Schaufeli, W.B., Maslach, C. and Marek, T. (Eds) Professional Burnout: Recent Developments in Theory and Research, Taylor and Francis, Washington, DC, pp. 19-32.

Meyers, L.S., Gamst, G. and Guarino, A.J. (2006), Applied Multivariate Research: Design and Interpretation, Sage, Thousand Oaks, CA.

Molenaar, K., Washington, S. and Diekmann, J.E. (2000), "Structural equation model of construction contract dispute potential", Journal of Construction Engineering and Management, Vol. 126 No. 4, pp. 268-277.

Moorhead, G. and Griffin, R.W. (1995), Organizational Behavior: Managing People and Organizations, Houghton Mifflin, Boston, MA.

Ng, S.T., Skitmore, R.M. and Leung, T.K. (2005), "Manageability of stress among construction project participants", Engineering, Construction and Architectural Management, Vol. 12 No. 3, pp. 264-282.

Nwaogu, J.M., Chan, A.P., Hon, C.K. and Darko, A. (2020), "Review of global mental health research in the construction industry", Engineering, Construction and Architectural Management, Vol. 27 No. 2, pp. 385-410.

Nicol, D. and Pilling, S. (2000), "Architectural education and the profession”, in Nicol, D. and Pilling, S. (Eds), Changing Architectural Education: Towards a New Professionalism, Spon Press, New York, NY, pp. 1-21.

Nunnally, J.C. and Bernstein, I.H. (2007), Psychometric Theory, McGraw-Hill, New York, NY.

Ostwald, M.J. and Williams, A. (2008), Understanding Architectural Education in Australasia, Vol: 1 an Analysis of Architecture Schools, Programs, Academics and Students, Australian Learning and Teaching Council, Sydney.

Pallant, J. (2001), SPSS Survival Manual: A Step by Step Guide to Data Analysis Using SPSS for Windows (Version 10), Open University Press, Milton Keynes.

Parilla, E.S. (2012), "Level of stress experienced by NWU employees: towards developing a stress management”, Asian Journal of Management Research, Vol. 2 No. 2, pp. 778-781.

Rauf, H.L. Gunce, K. and Ozgur Ozersay, M. (2020), "Self-advocacy for first-year students in interior architecture design studios", Open House International, available at: https://doi.org/10.1108/OHI05-2020-0041 
$\mathrm{OHI}$

46,2

RIBA Survey (2017), "RIBA education statistics 2015-16", Higher Education, Mirza \& Nacey Research for the RIBA, available at: www.architecture.com/-/media/gathercontent/ education-statistics/additional-documents/educationstatistics201516pdf.pdf (accessed 15 December 2020).

RIBA Survey (2018), "RIBA education statistics 2016-17", Higher Education, Mirza \& Nacey Research for the RIBA, available at: www.architecture.com/-/media/gathercontent/education-statistics/ additionaldocuments/educationstatistics201617pdf.pdf (accessed 15 December 2020).

Robotham, D. (2008), "Stress among higher education students: towards a research agenda", Higher Education, Vol. 56 No. 6, pp. 735-746.

Robotham, D. and Julian, C. (2006), "Stress and the higher education student: a critical review of the literature", Journal of Further and Higher Education, Vol. 30 No. 2, pp. 107-117.

Ross, S.E., Niebling, B.C. and Heckert, T.M. (1999), "Sources of stress among college students", Social Psychology, Vol. 61 No. 5, pp. 841-846.

Sawruk, T.R. (2015), "A policy brief: how can the america competes act (2011) better support the academic success of African American women in STEM degree programs?", Civil Engineering and Architecture, Vol. 3 No. 5, pp. 121-127.

Schön, D. (1985), The Design Studio: An Exploration of Its Traditions and Potential, RIBA Publications for RIBA Building Industry Trust, London.

Shah, M., Hasan, S., Malik, S. and Sreeramareddy, C.T. (2010), "Perceived stress, sources and severity of stress among medical undergraduates in a Pakistani medical schools", BMC Medical Education, Vol. 10 No. 1, pp. 1-8.

Şimşek, Ö.F. (2007), "Introduction to structural equation modelling", Basic Principles and Applications of LISREL, Ekinoks Publications, Ankara, Vol. 212.

Sohail, N. (2013), "Stress and academic performance among medical students", J Coll Physicians Surg. Pak, Vol. 23 No. 1, pp. 67-71.

Stroud, L.R., Salovey, P. and Epel, E.S. (2002), "Sex differences in stress responses: social rejection versus achievement stress", Biological Psychiatry, Vol. 52 No. 4, pp. 318-327.

Sun, M., Zhu, F. and Sun, X. (2020), "Influencing factors of construction professionals' burnout in China: a sequential mixed-method approach", Engineering, Construction and Architectural Management, Vol. 27 No. 10, doi: 10.1108/ECAM-02-2020-0106.

Sun, J., Dunne, M.P., Hou, X.Y. and Xu, A.Q. (2011), "Educational stress scale for adolescents: development, validity, and reliability with chinese students", Journal of Psychoeducational Assessment, Vol. 29 No. 6, pp. 534-546.

Szabo, Z. and Marian, M. (2017), "Stressors and reactions to stress: a Cross-Cultural case study in two educational programs", Journal of Evidence-Based Psychotherapies, Vol. 17 No. 1, pp. 89-103.

Tavakol, M. and Dennick, R. (2011), "Making sense of cronbach's alpha”, International Journal of Medical Education, Vol. 2, pp. 53-55.

UIA (2011), "UNESCO/UIA charter for architectural education revised edition 2011", Approved by UIA General Assembly, Tokyo available at: https://etsab.upc.edu/ca/shared/a-escola/a3-garantia-dequalitat/validacio/0_chart.pdf (accessed 11 May 2020).

Waite, R. and Braidwood, E. (2016), "Mental health problems exposed by AJ student survey 2016", The Architects Journal (accessed 28 July 2016).

Waite, R. and Jessel, E. (2019), "AJ student survey 2019: the harsh realities of life in practice", The Architects Journal, available at: www.architectsjournal.co.uk/news/aj-student-survey-2019-theharsh-realities-of-life-in-practice (accessed 3 October 2020).

Xie, Y., Yaqoob, A., Mansell, W. and Tai, S. (2019), "A qualitative investigation of stress related to studying architecture at degree level in the UK", Arts and Humanities in Higher Education, Vol. 1, doi: 10.1177/1474022219871001. 
Yunyan, A.J., Rowlinson, S., Kvan, T., Lingard, H.C. and Yip, B. (2009), "Burnout among Hong Kong chinese architecture students: the paradoxical effect of confucian conformity values", Construction Management and Economics, Vol. 27 No. 3, pp. 287-298.

Zawawi, D. and Jye, K.S. (2012), "Understanding the stressors and coping strategies among MBA students in Malaysia", International Conference on Business and Management, Phuket, pp. 6-7.

Zeidner, M. (1992), "Sources of academic stress: the case of first year jewish and arab college students in Israel", Higher Education, Vol. 24 No. 1, pp. 25-40.

Corresponding author

Gülden Gümüşburun Ayalp can be contacted at: gulden.ayalp@hku.edu.tr

For instructions on how to order reprints of this article, please visit our website: www.emeraldgrouppublishing.com/licensing/reprints.htm Or contact us for further details: permissions@emeraldinsight.com 